\title{
Essays on international trade
}

Citation for published version (APA):

Ndubuisi, G. O. (2021). Essays on international trade: the role of institutions and imported intermediate inputs. [Doctoral Thesis, Maastricht University]. Maastricht University. https://doi.org/10.26481/dis.20211012gn

Document status and date:

Published: 01/01/2021

DOI:

10.26481/dis.20211012gn

Document Version:

Publisher's PDF, also known as Version of record

\section{Please check the document version of this publication:}

- A submitted manuscript is the version of the article upon submission and before peer-review. There can be important differences between the submitted version and the official published version of record.

People interested in the research are advised to contact the author for the final version of the publication, or visit the DOI to the publisher's website.

- The final author version and the galley proof are versions of the publication after peer review.

- The final published version features the final layout of the paper including the volume, issue and page numbers.

Link to publication

\footnotetext{
General rights rights.

- You may freely distribute the URL identifying the publication in the public portal. please follow below link for the End User Agreement:

www.umlib.nl/taverne-license

Take down policy

If you believe that this document breaches copyright please contact us at:

repository@maastrichtuniversity.nl

providing details and we will investigate your claim.
}

Copyright and moral rights for the publications made accessible in the public portal are retained by the authors and/or other copyright owners and it is a condition of accessing publications that users recognise and abide by the legal requirements associated with these

- Users may download and print one copy of any publication from the public portal for the purpose of private study or research.

- You may not further distribute the material or use it for any profit-making activity or commercial gain

If the publication is distributed under the terms of Article $25 \mathrm{fa}$ of the Dutch Copyright Act, indicated by the "Taverne" license above, 


\section{SUMMARY}

The rapid increase in global trade which characterizes the current wave of globalization promises economic prosperity, especially for countries with good soft and hard infrastructures, and macroeconomic conditions. This has spurred a strand of literature examining the factors that enhance or hinder a country's participation in cross-border trade or its ability to gain the economic prosperity associated with cross-border trade. This dissertation makes a direct contribution to this literature by focusing on three related, but self-contained essays. Hence, while Chapter 1 of the thesis presents the general motivation and background of the three empirical essays, Chapter 2 examines how capital controls affect a country's export activities. To address this question, I exploit variation in capital control across countries and variation in external finance dependence across industries. Results from the analysis indicate that capital controls adversely affect exports, with the effect being higher in sectors that depend more on external finance. One of the major takeaways from the chapter is, therefore, that a country's industry composition can shape the effect of capital controls in the local economy, with capital controls tending to lead to comparative disadvantage in external finance dependent sectors. Hence, a country specializing in sectors that depend extensively on external finance may do well for itself by avoiding policies that restrict cross-border capital flows especially when the domestic credit market is underdeveloped.

Chapter 3 examines how imported intermediate inputs affect exported variety across manufacturing industries in Africa. It also examines the role of absorptive capacity in shaping the nature of this relationship. Results from the analysis show strong evidence of a positive relationship between imported intermediate inputs and the variety of exported products. The results also show that the positive effect of imported intermediate inputs on the variety of exported products tends to depend on industry's absorptive capacity, especially when the intermediate inputs are sourced from advanced countries, which may be reflective of their high-embodied technology content and the technological capacity gap between manufacturing industries in Africa and those in the advanced countries. Hence, while the results show that imported intermediate inputs are essential source of manufacturing industry upgrading in African countries, the finding that absorptive capacity is a pre-requisite for reaping the benefits of imported intermediate inputs from developed countries brings to front the options policy-makers in Africa must be aware. That is, sourcing inputs from other developing countries requires little additional absorptive capabilities to be built (if need be), 
while sourcing inputs from advanced countries requires intensive investments in building absorptive capacities.

Chapter 4 examines how patent enforcement affects the quality of exported products. I identify the effect of patent enforcement on product-quality by exploiting the variation in patent enforcement across countries and the variation in R\&D-intensity across industries (as a measure of an industry's dependence on patent enforcement). Results from the chapter shows that R\&D-intensive industries export higher product qualities in countries with more effective patent enforcement relative to those industries in countries with lower patent enforcement levels. In which case, countries seeking to specialize in the production and export of higher quality in R\&D-intensive sectors require effective patent enforcement as a means of encouraging technology exchange and investment in those sectors.

Overall, the findings of the thesis suggest that national policies and institutions matter for crossborder trade, but sector characteristics and a country's idiosyncrasies can either reinforce or attenuate the effects of policies and institutions on trade. The concluding remarks, policy implication and limitations of the thesis as well as areas for future research are presented in Chapter 5. 